\title{
The capital market spillover effect of product market advertising: Evidence from stock price synchronicity
}

\author{
Yajie Chen, Qinlin Zhong ${ }^{*}$ and Fuxiu Jiang
}

\author{
* Correspondence: zhongqinlin@ \\ rmbs.ruc.edu.cn \\ Business School, Renmin University \\ of China, Beijing 100872, China
}

\begin{abstract}
We analyze whether product market advertising has a spillover effect on stock price synchronicity by transmitting firm-specific information to the capital market and attracting more investor attention. Using a sample of Chinese listed firms from 2009 to 2017, we find that firms with greater advertising expenditures have lower stock price synchronicity. The results are robust after we address endogeneity concerns. In accord with our hypothesis that product market advertising increases the amount of firm-level information capitalized into stock prices through the information channel, we find that the impact of advertising on synchronicity is more pronounced for firms with a higher degree of information asymmetry and firms in the consumer-product industry. Further tests show that product market advertising enhances the ability of current period returns to reflect future earnings, and thus rules out that the negative relationship between advertising and synchronicity is driven by noise trading. Our results imply that product market advertising plays an informative role and improves information efficiency in a capital market.
\end{abstract}

Keywords: Advertising, Stock price synchronicity, Spillover effect, Product market, Capital market, Investor attention, Information asymmetry

\section{Introduction}

Product market advertising is a key mechanism for firms to convey information to the consumer (Nelson 1974). As an important marketing tool, advertising can transmit the messages that describe a product's characteristics, increase brand recognition among consumers, and stimulate consumers' brand love and mass consumption (Jun et al. 2009). As Madsen and Niessner (2019) point out, consumers and investors do not represent distinct groups, and the overlap between the two groups provides conditions for advertisements' spillover effect. Therefore, firms can opportunistically use product market advertising to attract investor attention and increase firms' visibility to investors.

Only a few studies have examined the spillover effect of product market advertising in a capital market. Grullon et al. (2004) explore the impact of advertising on the liquidity and breadth of ownership of stocks, and Lou (2014) shows that advertising can increase shortterm stock returns. In order to distinguish themselves in both product market and capital

(c) The Author(s). 2020 Open Access This article is licensed under a Creative Commons Attribution 4.0 International License, which permits use, sharing, adaptation, distribution and reproduction in any medium or format, as long as you give appropriate credit to the original author(s) and the source, provide a link to the Creative Commons licence, and indicate if changes were made. The images or other third party material in this article are included in the article's Creative Commons licence, unless indicated otherwise in a credit line to the material. If material is not included in the article's Creative Commons licence and your intended use is not permitted by statutory regulation or exceeds the permitted use, you will need to obtain permission directly from the copyright holder. To view a copy of this licence, visit http://creativecommons.org/licenses/by/4.0/. 
market, firms appear to use advertising in a strategic manner. For example, Chemmanur and Yan (2009) suggest that advertising campaigns undertaken by the firm in the product market are visible to the capital market, and firms choose a higher level of product market advertising when raising external financing. Oh et al. (2017) report that sinful firms increase advertising expenditures when they engage in a Corporate Social Responsibility (CSR) program. Fich et al. (2014) find that in the case of a merger, a target firm's manager will increase advertising in order to raise investor attention, improve their negotiation position and gain higher subsequent takeover premiums.

However, the extant studies on the spillover effect of product market advertising have never explored the economic consequences of advertising from the perspective of efficiency of information transmission. Information efficiency plays a constructive role in strengthening the function of price discovery and resource allocation of capital market. Stock price synchronicity reflects the degree of co-movement in stock prices and is the reflection of information efficiency. Our study fills this gap by examining whether the firms with greater advertising expenditures have lower stock price synchronicity and whether the negative relationship is more pronounced in firms with more severe information asymmetry.

Advertising, the most important institution driving consumer desires, has developed rapidly in China. Using firms covered in the China Stock Market and Accounting Research (CSMAR) database from 2009 to 2017, we find that the average advertising expenditure of firms listed on China's stock exchanges shows an upward trend from 2009 to 2017-from RMB16.9 million in 2009 to RMB85.9 million in 2017. The average advertising intensity, measured as advertising expenses scaled by sales revenue, also shows an overall upward trend.

The development of advertising is rooted in China's economic globalization, political liberalization, cultural transformation and technology development (Li 2016). The unique institutional characteristics shape both product market advertising and capital market efficiency, thus demonstrating the connection between these two important markets. Unlike in those mature stock markets in developed countries, individual investors comprise the majority and create the largest amount of transactions in China. Numerous poorly informed individual investors face huge costs in collecting and processing information in under-regulated stock markets. Limited investor attention causes them to rely more on their familiarity with firms instead of fundamental information when marking investment decisions. Not only does advertising extensively disseminate firm-specific information, but it also effectively influences market perceptions and increases investor attention, especially for individual investors rather than institutional investors (Grullon et al. 2004). Hence, product market advertising will create a larger spillover effect on capital markets in emerging economies. However, little is understood regarding the spillover effect of product market advertising in financial markets of emerging economies.

Using a sample of 1,840 Chinese listed firms (9,360 firm-year data) that reveals advertising expenses from 2009 to 2017, we investigate the impact of product market advertising on stock price synchronicity. Our results indicate that firms that spend more on advertising have lower stock price synchronicity. The empirical results are robust after including the firm characteristics and corporate governance control variables, and controlling for industry and year fixed effects.

The negative association between product market advertising and synchronicity may have been driven by endogeneity problems. For example, firms with lower synchronicity might be more willing to conduct advertising activities because of a higher degree of information 
transparency between insiders and outsiders. We would still observe a negative association between advertising and synchronicity, but it would not necessarily mean that product market advertising promotes the incorporation of firm-specific information into stock prices and reduces synchronicity. To mitigate endogeneity, we adopt the Two-Stage Least Squares (2SLS) instrumental variable model and conduct the Propensity Score Matching (PSM) procedure. The results are consistent with our main findings and seem to confirm that product market advertising tends to reduce stock price synchronicity. The main findings still hold when we control firm fixed effects or change the measurement of advertising intensity.

Further, we find that the negative relationship between product market advertising and synchronicity is more prominent for firms with a higher degree of information asymmetry, consistent with our contention that advertising helps firms transmit unique information to the market and attract investor attention, thus improving market efficiency. We also find that advertising has a stronger informative effect in consumer-product industry because more investor attention can be grabbed by advertising for consumer products. Besides, we find that product market advertising enhances the ability of current period returns to reflect future earnings and improves the informativeness of stock prices, ruling out the alternative explanation that the decline in synchronicity is the consequence of sentiment-driven noise trading affected by advertising.

This study contributes to the extant literature in three ways. First,it reinforces the link between product markets and financial markets. Following Brander and Lewis (1986), many studies on industrial organization have found that product market competition influences many aspects of capital markets, including stock market efficiency (Peress 2010), expected returns (Bustamante and Donangelo 2017), cost of debt (Valta 2012), and option prices (Morellec and Zhdanov 2019). Our study provides further evidence to support the correlation between product markets and capital markets by showing that advertising activities conducted by firms play an important role in disseminating more firm-specific information and drawing investor attention.

Second, our study contributes to the growing literature on the informative role of advertising by examining the relationship between product market advertising and stock price synchronicity. Previous studies have examined the impact of product market advertising on firm performance (Ho et al. 2005; Luo and de Jong 2012), insider trades (Frankel and Li 2004; Joseph and Wintoki 2013), and analysts' behavior (Barth et al. 2001; Gu and Wang 2005). Many studies also find that listed firms may strategically increase their advertising in order to increase takeover premiums (Fich et al. 2014), reduce cost of capital (Chemmanur and Yan 2009), improve the liquidity and breadth of ownership of common stocks (Grullon et al. 2004), and increase short-term stock returns (Lou 2014), among other things. However, to the best of our knowledge, this study is the first to examine how product market advertising impacts stock price informativeness. In this regard, our study enriches the literature on the economic consequences of product market advertising.

Third, our study also extends the literature on stock price synchronicity. A large amount of research investigates how stock price synchronicity is influenced by analyst coverage and forecasting activities (Chan and Hameed 2006; Piotroski and Roulstone 2004), firm disclosure policy (Haggard et al. 2008; Kim and Shi 2010), ownership structure (Boubaker et al. 2014; Gul et al. 2010; Jiang et al. 2018), law and political institutions (Fernandes and Ferreira 2009; Hasan et al. 2014), and press freedom (Kim et al. 2014). Our result provides new evidence to this fast-growing literature by examining 
how product market advertising affects synchronicity and finds a new determinant of stock price synchronicity.

The remainder of the paper is organized as follows. In Section "Literature review and hypothesis development," we review related literature and develop the research hypothesis. Section "Data and main variables" describes the data and research design, including the construction of sample, variables and summary statistics. Section "Empirical results" presents our empirical results. Section "Further analysis" conducts further analysis, including the roles of information, industrial differences and alternative explanations. Finally, we conclude in Section "Conclusion."

\section{Literature review and hypothesis development}

In an efficient market as described by Malkiel and Fama (1970), stock prices at any time fully reflect all available information and the capital market can play an effective role in resource allocation. Theoretically, if the market is fully efficient with respect to processing relevant information, the information conveyed by the advertisements is useless for investors. However, in the real world, stock price informativeness is substantially affected by friction such as information asymmetry (Stoll 2000). In this study, we focus on how advertising activities conducted by firms in the product market affect this friction, as manifested in stock price synchronicity. Specifically, we examine how the advertising intensity affects the information asymmetry between the firm and outsider investors, and how the product market advertising affects a firm's stock price synchronicity.

Product market advertising can provide firm-specific information to the capital market. On the one hand, advertising is informative. Nelson (1970) argues that direct information contained in the advertising statement helps consumers learn the existence, location, price, function and quality of products while indirect information contained in the advertising increases the reputability of brands and helps consumers learn the brand name and encourages them to buy it. Both direct and indirect information conveyed by advertising enables consumers to match with their respective preferred products (Meurer and Stahl 1994). Besides, advertising is an important means of implementing differentiation strategy (Telser 1964). Chamberlin (1933) and Grossman and Shapiro (1984) report that the firm can use advertising to differentiate products from those of its rivals, and the content of advertising often includes full and accurate information about the characteristics of the product. The unique information released to the market by advertisements is different from that of competitors and often contains firm-specific information.

In addition, investors can receive corporate information conveyed by advertising, which is the premise of the influence of advertising on capital market information efficiency. Madsen and Niessner (2019) state that consumers and investors do not necessarily represent distinct groups and individuals are more likely to invest in stocks they frequent as customers. Chemmanur and Yan (2009) also contend that product market advertising undertaken by the firm is visible to the capital market. Therefore, investors, important participants in the capital market, can also acquire firm-specific information through advertising campaign in the product market. As the receiver of advertising information, investors can not only obtain direct information about characteristics of products, such as their function and quality, but also capture indirect information about the true value of a firm's project signaled by advertising (Chamberlin 1933; Chemmanur and Yan 2009). In other words, although advertising typically contains no direct fundamental information regarding the stock's valuation (Aman 
et al. 2017), it can also be an effective way for listed firms to disseminate unique information to investors, thus affecting the incorporation of firm-specific information into stock prices.

Moreover, product market advertising can attract the attention of investors in capital markets and facilitate the impoundment of firm-specific information into stock prices. On the one hand, due to the limitation of time and information processing capacity, investors often have limited attention when facing a huge amount of information in the capital market and are more likely to respond to the information that grabs their attention (Barber and Odean 2008; Huberman 2001). Many studies have found that investors tend to buy stocks that catch their attention (Hong et al. 2007; Huberman and Regev 2001). Lou (2014) and Madsen and Niessner (2019) report that product market advertising aims to highlight firms' products and services and increase firm visibility, playing an important role in influencing investors' investment decisions because it is specifically designed to attract attention. Because information may not be incorporated into prices until it attracts the attention of investors (Corwin and Coughenour 2008), advertising can increase the trading volume of specific stock and improve the stock liquidity (Grullon et al. 2004; Lou 2014), leading to the increase in stock price informativeness.

Additionally, product market advertising can motivate investors to search for more firm-specific information on their own initiative. Ding and Hou (2015) and Grossman and Stiglitz (1980) suggest that in order to alleviate the information asymmetry towards listed firms, investors spend time and effort collecting relevant information, but the search cost is a major obstacle for investors to acquire firm-specific information. The timeliness and extensiveness of advertising can promote the flow and dissemination of firm-specific information among investors and reduce their search costs. Attracted by the advertisements, investors may actively collect and analyze the information of related firms, and then more information about the firm will be discovered. Undoubtedly, advertising plays a constructive role in raising investor attention and promoting the mining and incorporation of firm-specific information into stock prices.

Both the informative and attention-grabbing arguments suggest that product market advertising promotes the dissemination of information in the capital market and the incorporation of firm-specific information into stock prices. Hence, we develop the following hypothesis:

Hypothesis: Firms that spend more on advertising have lower stock price synchronicity.

\section{Data and main variables}

\section{Construction of sample}

Our initial sample includes all Chinese A-share exchange-listed firms that disclose advertising expenses from 2009 to 2017. Considering that the disclosure of advertising expenses is not mandatory and listed companies seldom disclose information about advertising expenses in their annual reports before 2008, our sample begins in 2009. We obtain advertising expenses data from the Wind Financial Database (WIND) and the Chinese Research Data Service Platform (CNRDS). Other financial statements and stock return data used in this study are obtained from the CSMAR database. Advertising expenses are calculated from the detailed items in "sales expenses" reported in the notes to the sample firms' annual financial statements.

Following previous studies, we exclude firms that operate in financial industries [China Securities Regulatory Commission (CSRC) code J] because their disclosure requirements 
and accounting rules significantly differ from non-financial industries. We also exclude firms which do not have a minimum of 30 consecutive trading weeks of stock data to enable our calculation of stock return synchronicity. Firms with missing or incomplete financial or governance data are also excluded. To manage the outlier problem, we winsorize all continuous variables at the $1 \%$ level in both tails. Our final sample consists of 9,360 firm-year observations for 1,840 unique firms.

\section{Variables}

\section{Independent variable: advertising intensity}

Consistent with prior studies (Chemmanur and Yan 2009; Ho et al. 2005; Simpson 2008), we construct advertising intensity $\left(A d_{i, t}\right)$ as the ratio of advertising expenses of firm $i$ in year $t$ to the sales revenue in the same year.

\section{Dependent variable: stock price synchronicity}

Following Chan and Chan (2014), Morck et al. (2000) and Piotroski and Roulstone (2004), we measure stock price synchronicity $\left(S y n_{i, t}\right)$ as follows. As a first step, for each week, we estimate the linear regression:

$$
R E T_{i, w, t}=\beta_{0}+\beta_{1} R E T_{M, w, t}+\beta_{2} R E T_{M, w-1, t}+\beta_{3} R E T_{I, w, t}+\beta_{4} R E T_{I, w-1, t}+\varepsilon_{i, w, t},
$$

where $R E T_{i, w, t}$ denotes the weekly return of firm $i, R E T_{M, w, t}$ is the value-weighted Ashare market return on week $w$, and $R E T_{I, w, t}$ denotes the value-weighted industry return. We measure industry returns using all firms within the same industry, omitting the weekly return for firm $i$.

Then following previous studies, we define stock price synchronicity for firm $i$ during year $t$ $\left(\mathrm{Syn}_{i, t}\right)$ as a logistic transformation of $R^{2}$ to circumvent the bounded nature of $R^{2}$ within [0, 1]:

$$
\operatorname{Syn}_{i, t}=\log \left(R^{2} /\left(1-R^{2}\right),\right.
$$

where $R^{2}$ is the coefficient of determination from the estimation of model (1) for firm $i$ in week $w$.

\section{Control variables}

Following Ben-Nasr and Cosset (2014), we control for several factors that have been shown to affect stock price synchronicity in prior studies. $D e b t_{i t}$ equals the book value of total liabilities divided by the book value of total assets. Size $e_{i t}$ is the natural logarithm of the book value of total assets at fiscal year-end. We also control for the market-to-book ratio $\left(M b_{\dot{v} t}\right)$, which is measured as the sum of the market value of tradable shares and book value of non-tradable shares divided by the book value of total assets at fiscal year-end. Turnover ${ }_{i t}$ is the total number of shares traded in a year divided by the total number of shares outstanding at fiscal year-end. Big4 $4_{i t}$ is a dummy variable that equals 1 if the firm hires an international Big 4 accounting firm in year $t$, and 0 otherwise. $A g e_{\underline{i j t}}$ denotes the number of years from IPO of firm $i . R_{0 a_{i t}}$ is the ratio of net profit divided by the book value of total assets at fiscal year-end. Institution $n_{\dot{v} t}$ is the percentage of shares held by institutional owners. Top $1_{i t}$ is the percentage of shares owned by the largest shareholder. $M s h_{i t}$ is a dummy variable that equals 1 if top managers hold shares, and 0 otherwise. Independent $t_{\dot{v} t}$ is the percentage of independent directors on a board. The Table 9 in Appendix presents detailed variable definitions. 


\section{Summary statistics}

Table 1 presents the summary statistics of variables used in the baseline analysis. The mean of sample firms' stock price synchronicity $\left(S y n_{i, t}\right)$ is -0.284 , and the median is -0.236; these figures are similar to those reported by Hasan et al. (2014). The mean of advertising intensity $\left(A d_{i, t}\right)$ is 0.016 , indicating that advertising expenses of Chinese listed companies account for $1.6 \%$ of sales revenue on average during the sample period. The $75 \%$ quantile of $A d_{i, t}$ is 0.012 , whereas the $25 \%$ quantile is close to 0 , demonstrating a varied degree of advertising intensity among the firms. The mean (median) of Debt $_{i, t}$ is 0.460 (0.459); the mean (median) of Size $_{i, t}$ is 22.201 (22.067); the mean (median) of book-tomarket ratio $\left(M b_{i, t}\right)$ is 1.731 (1.273); and the mean (median) of Turnover $_{i, t}$ is 1.710 (1.354). The statistics for other control variables are in reasonable ranges and similar to previous studies that examine the stock price synchronicity of Chinese listed firms.

\section{Empirical results}

To investigate the effect of advertising intensity on stock price synchronicity, we first estimate the following regression:

$$
\operatorname{Syn}_{i, t}=\alpha+\beta_{1} A d_{i, t}+\gamma X+\text { Year }+ \text { Industry }+\varepsilon_{i, t},
$$

where $S y n_{i, t}$ is the synchronicity measure in model (2) and represents stock price synchronicity for firm $i$ in year $t$; $A d_{i, t}$ represents advertising intensity for firm $i$ in year $t$; and $X$ is an array of control variables that could affect a firm's stock price synchronicity discussed in Section "Control variables." We also control for industry and time fixed effects. If the product market advertising can promote the incorporation of firm-specific information into stock prices, we expect a negative $\beta_{1}$.

\section{Baseline regression results}

Table 2 presents the baseline regression results using OLS with standard errors clustered at the firm level. In column (1), we report the regression results of the impact of advertising intensity on stock price synchronicity including $A d_{i, t}$ alone in the model (3). Columns (2) and (3) show the results with the further inclusion of relevant firm

Table 1 Summary statistics

\begin{tabular}{lllllll}
\hline Variable & No. of obs. & Mean & S.D. & P25 & Median & P75 \\
\hline Syn & 9,360 & -0.284 & 0.821 & -0.809 & -0.236 & 0.305 \\
Ad & 9,360 & 0.016 & 0.037 & 0.001 & 0.003 & 0.012 \\
Debt & 9,360 & 0.460 & 0.209 & 0.296 & 0.459 & 0.623 \\
Size & 9,360 & 22.201 & 1.198 & 21.386 & 22.067 & 22.886 \\
Mb & 9,360 & 1.731 & 2.124 & 0.777 & 1.273 & 2.074 \\
Turnover & 9,360 & 1.710 & 1.252 & 0.794 & 1.354 & 2.276 \\
Big4 & 9,360 & 0.051 & 0.220 & 0.000 & 0.000 & 0.000 \\
Age & 9,360 & 2.425 & 0.608 & 1.946 & 2.639 & 2.944 \\
Roa & 9,360 & 0.039 & 0.050 & 0.013 & 0.034 & 0.063 \\
Institution & 9,360 & 0.408 & 0.225 & 0.234 & 0.417 & 0.577 \\
Top 1 & 9,360 & 0.346 & 0.150 & 0.228 & 0.323 & 0.449 \\
Msh & 9,360 & 0.767 & 0.423 & 1.000 & 1.000 & 1.000 \\
Independent & 9,360 & 0.372 & 0.054 & 0.333 & 0.333 & 0.400 \\
\hline
\end{tabular}


Table 2 Baseline regression

\begin{tabular}{llll}
\hline Variable & (1) & (2) & $(3)$ \\
\hline Ad & $-1.043^{\mathrm{a}}(-3.86)$ & Syn & Syn \\
Debt & & $-1.073^{\mathrm{a}}(-3.97)$ & $-1.067^{\mathrm{a}}(-3.95)$ \\
Size & & $-0.262^{\mathrm{a}}(-4.30)$ & $-0.258^{\mathrm{a}}(-4.25)$ \\
Mb & & $0.017(1.07)$ & $0.016(0.99)$ \\
Turnover & $-0.043^{\mathrm{b}}(-2.37)$ & $-0.044^{\mathrm{b}}(-2.38)$ \\
Big4 & $-0.104^{\mathrm{a}}(-11.67)$ & $-0.109^{\mathrm{a}}(-12.21)$ \\
Age & & $-0.139^{\mathrm{a}}(-3.31)$ & $-0.134^{\mathrm{a}}(-3.20)$ \\
Roa & & $0.058^{\mathrm{a}}(3.43)$ & $0.050^{\mathrm{a}}(2.83)$ \\
Institution & & $-0.051(-0.26)$ & $-0.043(-0.22)$ \\
Top1 & $-0.284^{\mathrm{a}}(-5.73)$ & $-0.238^{\mathrm{a}}(-4.58)$ \\
Msh & & $-0.176^{\mathrm{a}}(-2.63)$ \\
Independent & & $0.014(0.71)$ \\
Cons & & & $0.073(0.46)$ \\
Year fixed effects & & & $0.263(0.70)$ \\
Industry fixed effects & & $0.194(0.52)$ & Yes \\
No. of obs. & Yes & Yes & Yes \\
Adj. $R^{2}$ & $9.026(0.21)$ & Yes & 9,360 \\
\hline
\end{tabular}

Notes. Numbers in parentheses are $t$-statistics based on standard errors clustered by firm when we control for year and industry effects

${ }^{\mathrm{a}}$ and ${ }^{\mathrm{b}}$ denote statistical significance at the $1 \%, 5 \%$, and $10 \%$ levels, respectively

characteristic and corporate governance control variables. The coefficients of $A d_{i, t}$ in columns (1)-(3) are negative and statistically significant at the $1 \%$ level. This evidence is consistent with our hypothesis, suggesting that firms with higher advertising intensity tend to have lower stock price synchronicity. The result is consistent with the notion that due to the informative role of advertising, firms that are more advertising intensive provide more firm-specific information for the market and draw more investor attention, leading to lower stock price synchronicity.

The coefficients of control variables are generally consistent with prior studies (e.g., Boubaker et al. 2014), firms with lower turnover, lower market to book ratio and lower institution ownership are associated with lower stock price synchronicity.

\section{Endogeneity}

Although the negative relationship between advertising intensity and stock price synchronicity shown in Table 2 is consistent with our hypothesis, the results may have been affected by omitted variables or reverse causality. Specifically, there could have been observable or unobservable firm characteristics affecting both advertising expenditure and synchronicity. Furthermore, firms with lower synchronicity might be more willing to conduct advertising activities because of their more transparent information environment.

We address the potential endogeneity issue in several ways, including adopting the 2SLS instrumental variable model, the PSM procedure, the fixed effects model, and the alternative measurement of advertising intensity. 


\section{$2 S L S$ instrumental variable model}

A firm's decision to invest in advertising may not be exogenous and some unobserved firm characteristics could link the advertising expenses and stock price synchronicity, resulting in biased OLS coefficients. To address this concern, we use the 2SLS instrumental variable model and seek instruments that proxy for a firm's advertising expenses that are not related to the potential unobserved firm characteristics. Specifically, we use the $I V_{-} A d_{i, t}$ (the mean of advertising intensity for firms in the same industry in the same year, excluding the firm concerned) as our instrumental variable. ${ }^{1}$ It seems reasonable that a firm's advertising expenditure may be related to the overall level of advertising intensity in the firm's industry because competitors' advertising activities influence the firm's decision whether to advertise or not (Simpson 2008). We expect that a firm's advertising intensity would be correlated with the industry average, but a firm's stock price synchronicity seems unlikely to affect the industry average advertising expenditure. That is, this instrumental variable attains the inclination of firms within the same industry to advertise.

The results of instrumental variable estimation are reported in Table 3. We obtain the predicted values of $A d_{i t}$ in the first stage of the regression. The predicted value of the variable $\left(H \_A d\right)$ is used to replace the original variables. The results in the first stage show that the predicted value of $A d_{i, t}$ is positive and significant at the $1 \%$ level, which is consistent with our expectation that more advertising activities are conducted by firms in advertising intensive industries. Overall, the results in Table 3 provide support for the notion that product market advertising is able to incorporate more firm-specific information into stock prices, so that the synchronicity of firms with higher advertising intensity is, on average, lower than that of firms spending less on advertising. These findings suggest that the omitted variables do not seem to affect our main results. The Cragg-Donald Wald $F$-statistic is significant at the $1 \%$ level in Table 3, suggesting that the selected instrument performs well.

\section{PSM procedure}

We utilize the PSM procedure to alleviate the selection bias concern. With this procedure, we can compare firms with high advertising intensity to a set of firms with lower advertising intensity that are the same on all other observable dimensions, thus allowing us to more clearly attribute any observed effects to advertising intensity, rather than to other observable characteristics.

For each firm with high advertising intensity (treatment group), we select firms with lower advertising intensity as the control group based on firm-, corporate governance-, and industry-level characteristics, so that there is no significant difference between the treatment group and the control group except advertising intensity.

Specifically, referring to Serfling (2014), we first sort the samples according to the advertising intensity and divide them into three parts, eliminating the samples in the middle tercile. If the observation is in the largest advertising intensity tercile, the variable Large_ad equals 1 , and 0 otherwise. Secondly, we compute propensity scores by regressing Large_ad on Debt, Size, Mb, Turnover, Big4, Age, Roa, Institution, Top1, Msh, Independent and industry and year fixed effects. Then we use one-to-one nearest neighborhood matching method without replacement to match each observation with Large_ad that equals 1 to an observation

${ }^{1}$ We also follow Gordon and Hartmann (2013) and Gurun and Butler (2012) to use the HerfindahlHirschman Index in communication and cultural industries as instrumental variable, and the results remain the same. 
Table 3 2SLS instrumental variable model

\begin{tabular}{lll}
\hline Variable & First stage & Second stage \\
& $(1)$ & $(2)$ \\
\hline N_Ad & $1.027^{\mathrm{a}}(11.87)$ & $-2.027^{\mathrm{a}}(-3.15)$ \\
H_Ad & & $-0.272^{\mathrm{a}}(-4.47)$ \\
Debt & $-0.008^{\mathrm{c}}(-1.89)$ & $0.015(0.96)$ \\
Size & $-0.001(-0.76)$ & $-0.042^{\mathrm{b}}(-2.38)$ \\
Mb & $0.001^{\mathrm{c}}(1.65)$ & $-0.111^{\mathrm{a}}(-12.33)$ \\
Turnover & $-0.001^{\mathrm{a}}(-2.62)$ & $-0.127^{\mathrm{a}}(-3.00)$ \\
Big4 & $0.007^{\mathrm{b}}(2.17)$ & $0.055^{\mathrm{a}}(3.06)$ \\
Age & $0.002(1.27)$ & $0.043(0.21)$ \\
Roa & $0.061^{\mathrm{a}}(4.29)$ & $-0.235^{\mathrm{a}}(-4.58)$ \\
Institution & $0.001(0.44)$ & $-0.172^{\mathrm{b}}(-2.57)$ \\
Top1 & $0.004(0.72)$ & $0.016(0.79)$ \\
Msh & $0.001(0.78)$ & $0.067(0.42)$ \\
Independent & $-0.008(-0.68)$ & $0.278(0.75)$ \\
_Cons & $0.013(0.81)$ & Yes \\
Year fixed effects & Yes & Yes \\
Industry fixed effects & Yes & 9,360 \\
No. of obs. & 9,360 & 0.323 \\
With-in $R^{2}$ & 0.315 & \\
Cragg-Donald Wald $F$ & $2093.599^{\mathrm{a}}$ & \\
\hline Notes Nus & & \\
\hline
\end{tabular}

Notes. Numbers in parentheses are $t$-statistics based on standard errors clustered by firm when we control for year and industry effects ${ }^{a}, b$, and ${ }^{c}$ denote statistical significance at the $1 \%, 5 \%$, and $10 \%$ levels, respectively

with Large_ad that equals to 0 . We obtain a propensity-score-matched sample of 2,900 firms (1,450 higher advertising intensity firms and 1,450 lower advertising intensity firms).

Panel A of Table 4 reports mean differences in firm characteristic and corporate governance variables between treated (higher advertising intensity) firms and matching (lower advertising intensity) firms. We find that none of the variables is significantly different between the two groups, indicating that PSM procedure effectively identifies matching firms with lower advertising intensity.

Panel B of Table 4 reports the regression results in the sample of firms with higher advertising intensity and their matching firms. Columns (1)-(3) present the sample using 1:1, 1:2 and 1:3 the nearest-neighbor matching method, respectively. In sum, after using the propensity-score-matched sample to correct for any endogenous selection on observed variables, the results continue to imply a negative relation between product market advertising and stock price synchronicity.

\section{Robustness}

\section{Alternative measure of advertising}

In the baseline regression, we use advertising intensity to measure product market advertising. Following Grullon et al. (2004) and Oh et al. (2017), we employ advertising expenditure scaled by a firm's total assets $\left(A d_{-} 1\right)$ and the natural logarithm of 1 plus advertising expenditure $\left(A d \_2\right)$ as alternative measures of product market advertising, in order to avoid the inconsistency in estimators caused by measurement error in independent variable and ensure our findings are not sensitive to the measure of advertising. 
Table 4 Propensity score matching (PSM) procedure

\begin{tabular}{|c|c|c|c|c|c|c|}
\hline \multicolumn{7}{|c|}{ Panel A: Descriptive statistics for propensity-score-matched sample } \\
\hline \multirow[b]{2}{*}{ Variable } & \multicolumn{2}{|l|}{ Large_ad $=1$} & \multicolumn{2}{|c|}{ Large_ad $=0$} & \multicolumn{2}{|c|}{ Test of difference } \\
\hline & No. of obs. & Mean & No. of obs. & Mean & Mean & t-stat \\
\hline Debt & 1,450 & 0.445 & 1,450 & 0.449 & -0.004 & -0.57 \\
\hline Size & 1,450 & 22.096 & 1,450 & 22.084 & 0.012 & 0.27 \\
\hline Mb & 1,450 & 1.802 & 1,450 & 1.788 & 0.014 & 0.22 \\
\hline Turnover & 1,450 & 1.733 & 1,450 & 1.707 & 0.026 & 0.55 \\
\hline Big4 & 1,450 & 0.052 & 1,450 & 0.049 & 0.003 & 0.34 \\
\hline Age & 1,450 & 2.391 & 1,450 & 2.382 & 0.009 & 0.37 \\
\hline Roa & 1,450 & 0.039 & 1,450 & 0.039 & 0.000 & -0.13 \\
\hline Institution & 1,450 & 0.399 & 1,450 & 0.403 & -0.004 & -0.5 \\
\hline Top1 & 1,450 & 0.338 & 1,450 & 0.347 & -0.009 & -1.55 \\
\hline Msh & 1,450 & 0.787 & 1,450 & 0.777 & 0.010 & 0.63 \\
\hline Independent & 1,450 & 0.345 & 1,450 & 0.375 & -0.030 & -0.41 \\
\hline
\end{tabular}

Panel B: The regression results using PSM procedure

\begin{tabular}{llll} 
& $(1)$ & $(2)$ & $(3)$ \\
Variable & Syn & Syn & Syn \\
Ad & $-1.116^{\mathrm{b}}(-2.34)$ & $-0.815^{\mathrm{a}}(-3.00)$ & $-0.751^{\mathrm{a}}(-2.79)$ \\
Debt & $-0.320^{\mathrm{a}}(-3.50)$ & $-0.306^{\mathrm{a}}(-3.98)$ & $-0.313^{\mathrm{a}}(-4.27)$ \\
Size & $0.018(0.91)$ & $-0.014(-0.87)$ & $-0.008(-0.52)$ \\
Mb & $-0.074^{\mathrm{a}}(-6.31)$ & $-0.088^{\mathrm{a}}(-7.85)$ & $-0.089^{\mathrm{a}}(-8.01)$ \\
Turnover & $-0.082^{\mathrm{a}}(-5.37)$ & $-0.092^{\mathrm{a}}(-7.38)$ & $-0.094^{\mathrm{a}}(-7.81)$ \\
Big4 & $-0.183^{\mathrm{b}}(-2.39)$ & $-0.148^{\mathrm{a}}(-2.92)$ & $-0.143^{\mathrm{a}}(-2.87)$ \\
Age & $0.067^{\mathrm{b}}(2.44)$ & $0.077^{\mathrm{a}}(3.51)$ & $0.071^{\mathrm{a}}(3.29)$ \\
Roa & $-0.119(-0.40)$ & $-0.290(-1.18)$ & $-0.268(-1.10)$ \\
Institution & $-0.149^{\mathrm{c}}(-1.92)$ & $-0.193^{\mathrm{a}}(-3.21)$ & $-0.190^{\mathrm{a}}(-3.20)$ \\
Top1 & $-0.251^{\mathrm{b}}(-2.31)$ & $-0.165^{\mathrm{c}}(-1.88)$ & $-0.184^{\mathrm{b}}(-2.13)$ \\
Msh & $-0.017(-0.52)$ & $0.009(0.33)$ & $0.014(0.53)$ \\
Independent & $0.070(0.28)$ & $0.211(1.06)$ & $0.257(1.32)$ \\
Cons & $0.258(0.48)$ & $0.814^{\mathrm{b}}(2.22)$ & $0.738^{\mathrm{b}}(2.07)$ \\
Year fixed effects & Yes & Yes & Yes \\
Industry fixed effects & Yes & 4,708 & Yes \\
No. of obs. & 2,900 & 0.332 & 5,022 \\
Adj. $R^{2}$ & 0.324 & 0.334 \\
\hline
\end{tabular}

Notes.Numbers in parentheses are $t$-statistics based on standard errors clustered by firm when we control for year and industry effects

${ }^{\mathrm{a}}, \mathrm{b}$, and ${ }^{\mathrm{C}}$ denote statistical significance at the $1 \%, 5 \%$, and $10 \%$ levels, respectively

We repeat our baseline regression using two new measures and report the results in Table 5. As shown, in columns (1) and (2), the coefficients of $A d \_1$ and $A d \_2$ are significantly negative at the $1 \%$ level, consistent with our finding that product market advertising negatively affects stock price synchronicity.

Firm fixed effects

To mitigate potential problems that may arise from omitting unobservable, timeinvariant firm characteristics, we re-estimate the regression of model (3) using the firm 
Table 5 Alternative measure of advertising and controlling for firm fixed effects

\begin{tabular}{|c|c|c|c|}
\hline \multirow[t]{2}{*}{ Variable } & (1) & (2) & (3) \\
\hline & Syn & Syn & Syn \\
\hline$A d_{-} 1$ & $-1.888^{\mathrm{a}}(-4.45)$ & & \\
\hline$A d \_2$ & & $-0.012^{\mathrm{a}}(-2.91)$ & \\
\hline Ad & & & $-0.887^{b}(-2.05)$ \\
\hline Debt & $-0.247^{\mathrm{a}}(-4.04)$ & $-0.244^{\mathrm{a}}(-3.96)$ & $-0.046(-0.48)$ \\
\hline Size & $0.015(0.97)$ & $0.027(1.63)$ & $-0.133^{\mathrm{a}}(-4.24)$ \\
\hline Mb & $-0.043^{b}(-2.35)$ & $-0.045^{b}(-2.37)$ & $-0.050^{\mathrm{a}}(-3.35)$ \\
\hline Turnover & $-0.109^{\mathrm{a}}(-12.28)$ & $-0.107^{\mathrm{a}}(-12.09)$ & $-0.209^{\mathrm{a}}(-20.20)$ \\
\hline Big4 & $-0.136^{a}(-3.22)$ & $-0.135^{\mathrm{a}}(-3.22)$ & $-0.027(-0.32)$ \\
\hline Age & $0.051^{\mathrm{a}}(2.89)$ & $0.045^{b}(2.54)$ & $0.189^{\mathrm{a}}(2.61)$ \\
\hline Roa & $0.009(0.04)$ & $-0.042(-0.21)$ & $0.693^{\mathrm{a}}(3.03)$ \\
\hline Institution & $-0.229^{\mathrm{a}}(-4.44)$ & $-0.234^{\mathrm{a}}(-4.46)$ & $-0.443^{\mathrm{a}}(-6.81)$ \\
\hline Top1 & $-0.172^{\mathrm{a}}(-2.59)$ & $-0.180^{\mathrm{a}}(-2.70)$ & $-0.281^{c}(-1.81)$ \\
\hline Msh & $0.015(0.77)$ & $0.017(0.82)$ & $0.041(1.29)$ \\
\hline Independent & $0.078(0.50)$ & $0.081(0.52)$ & $0.052(0.21)$ \\
\hline _Cons & $0.255(0.68)$ & $0.189(0.50)$ & $3.780^{\mathrm{a}}(5.46)$ \\
\hline Year fixed effects & Yes & Yes & Yes \\
\hline Industry fixed effects & Yes & Yes & Yes \\
\hline Firm fixed effects & No & No & Yes \\
\hline No. of obs. & 9,360 & 9,360 & 9,360 \\
\hline Adj. $R^{2}$ & 0.324 & 0.323 & 0.398 \\
\hline
\end{tabular}

Notes. Numbers in parentheses are $t$-statistics based on standard errors clustered by firm when we control for year and industry effects

a $b$, and ${ }^{c}$ denote statistical significance at the $1 \%, 5 \%$, and $10 \%$ levels, respectively

fixed effects model and report the results in Table 5. As shown in column (3), the estimated coefficient of the variable $A d_{i, t}$ is significantly negative at the $5 \%$ level. This implies that our results are not driven by time-invariant firm-specific characteristics.

\section{Further analysis}

\section{The roles of information}

According to the results of the baseline regression, a firm's higher advertising intensity can decrease the stock price synchronicity. We interpret the negative impact of advertising intensity on synchronicity as evidence that a firm's advertising activity can release the firm-specific information and attract investors' attention, alleviating the information asymmetry between the firm and outside investors. As documented in previous literature, information asymmetry between insiders and outsiders is an important reason for stock price synchronicity because it not only prevents firm-specific information from manifesting in capital market but also increases investors' information search costs (Haggard et al. 2008). We examine whether the negative relationship between advertising intensity and stock price synchronicity is more pronounced in firms subject to higher degree of information asymmetry to provide evidence for the information channel.

To test this proposition, we measure information asymmetry by following three proxies. The proxies include research and development $(\mathrm{R} \& \mathrm{D})$ investment $(R D)$, dispersion among analysts' forecasts (DISPEN), and stock illiquidity (ILLIQ). All three measures are defined in the Table 9 in Appendix. 
First, more R\&D activities mean a higher degree of information asymmetry (Barth et al. 2001). On the one hand, firms have weak incentives to disseminate R\&D-related information because $R \& D$ disclosure can lead to a higher proprietary cost and higher risk of leaking valuable private information to competitors. On the other hand, because of uncertain prospects and long product cycle, $R \& D$ activities have a higher degree of information asymmetry than other investments. In addition, listed firms have the discretion to use different accounting methods of $R \& D$ capitalization to manipulate earnings, and larger R\&D expenses give the firm more room for earnings manipulation and reduce the firm's information transparency. Therefore, a higher level of R\&D investment suggests a higher degree of information asymmetry. Column (1) in Table 6 presents the regression results. The coefficient of the interaction term between $A d$ and $R D$ is negative and significant at the $5 \%$ level. The result shows that the relationship between product market advertising and stock price synchronicity is more pronounced among firms with more R\&D activities.

Second, the dispersion among analysts' forecast reflects the accuracy or quality of firm's public and private information obtained by analysts and provides evidence for

Table 6 Interactive effects

\begin{tabular}{|c|c|c|c|c|}
\hline \multirow[t]{2}{*}{ Variable } & (1) & (2) & (3) & (4) \\
\hline & Syn & Syn & Syn & Syn \\
\hline Ad & $-0.780^{a}(-2.65)$ & $-0.508(-1.64)$ & $0.393(0.71)$ & $-0.740^{\mathrm{b}}(-2.29)$ \\
\hline$A d \times R D$ & $-0.168^{\mathrm{b}}(-1.96)$ & & & \\
\hline$R D$ & $-0.004(-0.78)$ & & & \\
\hline$A d \times D I S P E N$ & & $-0.999^{\mathrm{a}}(-2.86)$ & & \\
\hline DISPEN & & $-0.036(-1.03)$ & & \\
\hline$A d \times I L L I Q$ & & & $-0.986^{\mathrm{a}}(-2.69)$ & \\
\hline ILLIQ & & & $-0.010(-0.60)$ & \\
\hline AdxCONSU & & & & $-1.167^{b}(-2.25)$ \\
\hline CONSU & & & & $-0.040(-1.44)$ \\
\hline Debt & $-0.242^{\mathrm{a}}(-4.02)$ & $-0.254^{\mathrm{a}}(-3.96)$ & $-0.254^{\mathrm{a}}(-4.19)$ & $-0.250^{\mathrm{a}}(-4.10)$ \\
\hline Size & $0.015(0.92)$ & $-0.017(-1.29)$ & $0.015(0.98)$ & $0.015(0.92)$ \\
\hline Mb & $-0.043^{\mathrm{b}}(-2.41)$ & $-0.082^{\mathrm{a}}(-7.21)$ & $-0.043^{\mathrm{b}}(-2.37)$ & $-0.044^{\mathrm{b}}(-2.34)$ \\
\hline Turnover & $-0.109^{\mathrm{a}}(-12.27)$ & $-0.112^{\mathrm{a}}(-11.27)$ & $-0.108^{\mathrm{a}}(-12.17)$ & $-0.109^{\mathrm{a}}(-12.24)$ \\
\hline Big4 & $-0.137^{\mathrm{a}}(-3.28)$ & $-0.121^{\mathrm{a}}(-2.86)$ & $-0.136^{\mathrm{a}}(-3.25)$ & $-0.135^{\mathrm{a}}(-3.20)$ \\
\hline Age & $0.052^{\mathrm{a}}(2.98)$ & $0.067^{\mathrm{a}}(3.73)$ & $0.048^{\mathrm{a}}(2.72)$ & $0.050^{\mathrm{a}}(2.83)$ \\
\hline Roa & $-0.001(-0.01)$ & $-0.306(-1.36)$ & $-0.045(-0.23)$ & $-0.027(-0.14)$ \\
\hline Institution & $-0.228^{\mathrm{a}}(-4.41)$ & $-0.226^{\mathrm{a}}(-4.77)$ & $-0.238^{\mathrm{a}}(-4.62)$ & $-0.234^{\mathrm{a}}(-4.39)$ \\
\hline Top 1 & $-0.183^{\mathrm{a}}(-2.73)$ & $-0.195^{\mathrm{a}}(-2.84)$ & $-0.172^{\mathrm{b}}(-2.57)$ & $-0.173^{\mathrm{b}}(-2.57)$ \\
\hline Msh & $0.017(0.84)$ & $-0.011(-0.52)$ & $0.015(0.73)$ & $0.014(0.70)$ \\
\hline Independent & $0.120(0.77)$ & $0.097(0.60)$ & $0.076(0.49)$ & $0.080(0.51)$ \\
\hline _Cons & $0.276(0.74)$ & $1.010^{\mathrm{a}}(3.27)$ & $0.291(0.79)$ & $0.350(0.90)$ \\
\hline Year fixed effects & Yes & Yes & Yes & Yes \\
\hline Industry fixed effects & Yes & Yes & Yes & Yes \\
\hline No. of obs. & 9,350 & 7,946 & 9,360 & 9,324 \\
\hline Adj. $R^{2}$ & 0.327 & 0.338 & 0.325 & 0.325 \\
\hline
\end{tabular}


the firm's information environment. Prior studies (e.g., Li and Zhao 2008) show that disagreement among financial analysts is an indication of the lack of available information about the firm. The extent of dispersion among analysts' forecasts is associated with a higher degree of information asymmetry between insiders and outsiders. A high degree of information asymmetry makes analysts rely more on private information to forecast earnings, leading to greater dispersion among forecasts. Therefore, following Krishnaswami and Subramaniam (1999) and Thomas (2002), we use analysts' forecasts dispersion to measure information asymmetry. As can be seen from column (2) in Table 6, the interaction term of $A d$ and DISPEN is negatively related to Syn with statistical significance at the $1 \%$ level, indicating that the relationship between product market advertising and stock price synchronicity is more magnified among firms with greater dispersion among analysts' earnings forecast.

Third, existing empirical evidence shows that low stock liquidity is associated with a poor information environment. Higher liquidity means less impact of trading behavior on stock price formation, and it is easier for informed traders to disguise private information and make profits. Also, uninformed traders tend to pay for private information owned by informed traders, facilitating more information to be incorporated into stock prices (Holmstrom and Tirole 1993). In addition, because informed shareholders can buy large quantities of shares at a low price under the circumstances of high stock liquidity, they are motivated to gather more information on the firm, improving the informativeness of stock prices (Kyle and Vila 1991). Therefore, a higher level of stock illiquidity would indicate more severe information asymmetry. In column (3) of Table 6, results show that the coefficient of interaction term between Ad and ILLIQ is significantly negative at the $1 \%$ level, suggesting that the relationship between product market advertising and stock price synchronicity is much stronger in firms with low stock liquidity.

Overall, in accord with our expectations, these results suggest that the effect of advertising intensity on a stock price synchronicity is more prominent when the degree of firms' information asymmetry is higher, providing evidence for the information channel.

\section{The difference in industry}

Compared with firms in other industries, firms in consumer-product industry can moreextensively and intensively transmit firm-specific information through product market advertising and have lower stock price synchronicity because their advertising campaigns are more likely to attract investor attention (Lou 2014). On the one hand, the scope of the target group in advertising varies with the position of firm in commodity circulation. Because the products of consumer-product industry are oriented to the final consumers, the advertising in this industry speaks more directly to consumers so that more consumers can receive information related to the firm. On the other hand, there is an overlap between consumers and investors, so advertising in the consumer-product industry can increase investor attention while attracting consumers. Therefore, we divide firms into two categories according to whether the firm is in the consumer-product industry (CONSU) and expect that the negative relationship between product market advertising and stock price synchronicity is more prominent in those firms in the consumer-product industry.

Specifically, we use industry classification in the WIND database and measure CONSU as a dummy variable that equals 1 if the industry of a firm is classified as "consumer 
discretionary" or "consumer staples," and 0 otherwise. Consistent with our expectation, the result in column (4) of Table 6 shows that the interaction term of Ad and CONSU is negatively significant at the $5 \%$ level, indicating that product market advertising has a greater negative influence on stock price synchronicity in firms producing consumer products.

\section{Alternative explanation}

\section{Alternative explanation: noise trading}

There is a debate about the interpretation of synchronicity, that is, whether a lower synchronicity indicates better informed stock prices or is a response to irrational noise trading driven by sentiment. While several studies suggest that a lower synchronicity represents the incorporation of firm-specific information and price efficiency, other studies show that subjection to noise trading and a poor information environment lead to a decrease in synchronicity (Kelly 2014; Yang and Zhang 2006).

As evidenced in previous empirical results, product market advertising significantly reduces stock price synchronicity. One possible explanation is that product market advertising alleviates the information asymmetry between insiders and outsiders and incorporates more firm-specific information into the stock price, leading to an increase in the stock price informativeness and a decrease in synchronicity. Alternatively, it could be the case that lower synchronicity is caused by an occasional frenzy unrelated to concrete information because advertising influences investor sentiment, induces more noise trading, and reduces the explanatory power of market and industry information on stock prices.

Product market advertising can trigger temporary spikes in investor attention through newspapers, TV sets, the Internet, and more, creating bias towards brand-name stocks among investors and increasing sentiment-driven noise trading. On the one hand, firms have motivations to use false advertisement to mislead participants in both product market and capital market. By deliberately exaggerating effects or concealing part of the truth in advertisements, firms can promote the products and influence consumers' purchase decisions, to increase sales and profits. This in turn can mislead investors to perceive that the firm has a stronger competitive advantage and create investors' over-optimism about fundamental firm value. If investors fail to recognize and choose to trade with noise information, then the lower synchronicity may suggest the decrease in stock price informativeness and market efficiency. On the other hand, product market advertising can spur and propagate some degree of investor mania and lead to noise trading. Frieder and Subrahmanyam (2005) find that brand perceptions of firm's products spill over to investment decisions for firm's stock because investors prefer stocks of firms with high-visibility brands and easily recognized products. Thus, the brand awareness linked to advertising has a direct impact on the investors' incentive to hold stocks.

Is the decline in stock price synchronicity due to the noise trading influenced by product market advertising? To address this concern, we use a method similar to that of Choi et al. (2019) and examine the relationship between product market advertising and the ability of current period returns to reflect future earnings, measured by the future earnings response coefficient (FERC). If FERCs are higher for firms that conduct more advertising activities, stock prices of those firms reflect relatively more firm-specific information and allow investors to better anticipate future firm performance. This analysis allows us to examine the noise trading argument. We estimate the following model: 


$$
\begin{aligned}
R_{i, t}=\alpha & +\beta_{1} \text { Earnings }_{i, t-1}+\beta_{2} \text { Earnings }_{i, t}+\beta_{3} \text { Earnings }_{i, t+1}+\beta_{4} R_{i, t+1}+\beta_{5} \text { Ad }_{i, t} \\
& +\beta_{6} A_{i, t} \times \text { Earnings }_{i, t-1}+\beta_{7} \text { Ad }_{i, t} \times \text { Earnings }_{i, t}+\beta_{8} A d_{i, t} \times \text { Earnings }_{i, t+1} \\
& +\beta_{9} A_{i, t} \times R_{i, t+1}+\gamma \text { Controls }_{i, t}+\varepsilon_{i, t},
\end{aligned}
$$

where $R_{i, t}$ is the cumulative buy-and-hold return for firm $i$ in year $t$, and Earnings $s_{i, t}$ is the income scaled by beginning market value of equity for firm $i$ in year $t$. Following previous studies, we include several control variables: Size, Debt, Bm, Growth, and Coverage.

If advertising improves the market's ability to anticipate future earnings, the coefficient on the interaction between advertising intensity and future earnings $\left(\beta_{8}\right)$ in model (4) will be positive. The positive coefficient suggests an increasing amount of firmspecific information reflected in stock prices, providing evidence for information channel, whereas the negative coefficient is consistent with noise argument, indicating that advertising causes noise trading that reduces the informativeness of stock prices.

Table 7 presents the results. We use operating income and net income as a proxy for the Earnings, respectively. Regardless of whether control variables are included, the coefficients of $A d_{i, t} \times$ Earnings $_{i, t+1}$ in columns (1)-(4) are positive and statistically significant at the $1 \%$ level, indicating that product market advertising helps more firmspecific information be incorporated into stock prices and helps investors better anticipate future firm performance. These findings seem to refute the alternative explanation that advertising triggers more sentiment-driven noise trading, leading to lower stock price synchronicity.

\section{Alternative explanation: product market competition}

Prior literature indicates that industry concentration is related to advertising and stock price synchronicity, providing an alternative explanation of product market competition. On the one hand, two opposing arguments exist in the literature regarding the relationship between advertising and competition. One view is that advertising can improve industry concentration because it promotes market power in leading firms by differentiating products and enhancing customer loyalty. The other view is that advertising might increase product market competition by increasing the quantity of information available to consumers regarding the prices and other attributes of alternative products. Advertising brings about fierce rivalry among extant firms and facilitation for new entrants (Eckard 1987).

On the other hand, extant studies provide conflicting results on the relation between product market competition and stock price synchronicity. The first view holds that firms in a more competitive environment have higher idiosyncratic volatility and lower stock price synchronicity. Firms acting in a highly competitive industry exhibit higher information uncertainty and higher return volatility (Gaspar and Massa 2006), while stronger market power inherent in concentrated industries smooths out a firm's idiosyncratic volatility (Abdoh and Varela 2017). Besides, industry concentration enhances dissemination of industry information, making industry-common information more useful in investors' decision-making, thus increasing stock price synchronicity (Haw et al. 2016). In contrast, the second view holds that product market competition can increase stock price synchronicity. Investors are inclined to trade stocks of firms that 
Table 7 Alternative explanation

\begin{tabular}{|c|c|c|c|c|}
\hline \multirow[t]{3}{*}{ Variable } & \multicolumn{2}{|c|}{ Earning = Operating income } & \multicolumn{2}{|c|}{ Earning $=$ Net income } \\
\hline & $R_{i, t}$ & $R_{i, t}$ & $R_{i, t}$ & $R_{i, t}$ \\
\hline & (1) & (2) & (3) & (4) \\
\hline $\operatorname{Ad}_{i, t} \times$ Earnings $_{i, t+1}$ & $26.911^{\mathrm{a}}(2.81)$ & $28.748^{\mathrm{a}}(3.08)$ & $22.910^{\mathrm{a}}(2.83)$ & $19.164^{\mathrm{b}}(2.37)$ \\
\hline Earnings $_{i, t-1}$ & $-1.550^{\mathrm{a}}(-8.40)$ & $-1.202^{\mathrm{a}}(-6.66)$ & $-1.385^{\mathrm{a}}(-8.78)$ & $-0.958^{\mathrm{a}}(-5.92)$ \\
\hline Earnings $_{i, t}$ & $1.252^{\mathrm{a}}(5.90)$ & $1.457^{\mathrm{a}}(6.87)$ & $0.951^{\mathrm{a}}(5.05)$ & $1.193^{\mathrm{a}}(5.85)$ \\
\hline Earnings $_{i, t+1}$ & $0.872^{\mathrm{a}}(4.97)$ & $1.022^{\mathrm{a}}(5.82)$ & $0.843^{\mathrm{a}}(5.33)$ & $0.788^{\mathrm{a}}(4.80)$ \\
\hline$R_{i, t+1}$ & $-0.130^{\mathrm{a}}(-7.98)$ & $-0.129^{a}(-8.08)$ & $-0.130^{\mathrm{a}}(-8.03)$ & $-0.125^{\mathrm{a}}(-7.26)$ \\
\hline$A d_{i, t}$ & $-0.215(-0.78)$ & $-0.362(-1.37)$ & $-0.276(-1.10)$ & $-0.373(-1.46)$ \\
\hline$A d_{i, t} \times$ Earnings $_{i, t-1}$ & $-16.988^{\mathrm{b}}(-2.12)$ & $-16.037^{b}(-2.02)$ & $-14.822^{\mathrm{b}}(-2.02)$ & $-13.887^{\complement}(-1.86)$ \\
\hline Ad $_{i, t} \times$ Earnings $_{i, t}$ & $-4.856(-0.48)$ & $-3.339(-0.33)$ & $-3.382(-0.37)$ & $3.144(0.33)$ \\
\hline$A d_{i, t} \times R_{i, t+1}$ & $0.165(0.28)$ & $0.170(0.29)$ & $0.113(0.19)$ & $-0.338(-0.56)$ \\
\hline Size & & $-0.046^{\mathrm{a}}(-5.82)$ & & $-0.041^{\mathrm{a}}(-5.86)$ \\
\hline Debt & & $0.210^{\mathrm{a}}(5.48)$ & & $0.196^{\mathrm{a}}(5.11)$ \\
\hline$B m$ & & $-0.027^{\mathrm{a}}(-3.84)$ & & $-0.028^{\mathrm{a}}(-4.13)$ \\
\hline Growth & & $0.004(0.43)$ & & $0.005(0.48)$ \\
\hline Coverage & & $-0.008(-1.37)$ & & $-0.015^{b}(-2.57)$ \\
\hline _Cons & $0.081(1.00)$ & $0.948^{\mathrm{a}}(5.39)$ & $0.105(1.36)$ & $0.824^{a}(5.54)$ \\
\hline Year fixed effects & Yes & Yes & Yes & Yes \\
\hline Industry fixed effects & Yes & Yes & Yes & Yes \\
\hline No. of obs. & 5,094 & 5,094 & 5,094 & 5,094 \\
\hline Adj. $R^{2}$ & 0.114 & 0.130 & 0.115 & 0.071 \\
\hline
\end{tabular}

Notes. The independent variable of columns (1) and (2) is operating income for firm $i$ at fiscal year-end. Column (2) shows the results with the inclusion of control variables on the basis of column (1). The independent variable of columns (3) and (4) is net income for firm $i$ at fiscal year-end. Column (4) shows the results with the inclusion of control variables on the basis of column (3). Numbers in parentheses are $t$-statistics based on standard errors clustered by firm when we control for year and industry effects

$a, b$, and ${ }^{c}$ denote statistical significance at the $1 \%, 5 \%$, and $10 \%$ levels, respectively

operate in concentrated industries in larger quantities because profits of those firms are less risky than of firms in competitive industries. As for firms faced with tougher competitive conditions, smaller trade volume impedes the incorporation of private information into prices, thus stock prices are less informative (Peress 2010).

To address this concern of alternative explanation, we add variables that proxy for product market competition as additional control variables. Following Abdoh and Varela (2017) and Markarian and Santalo (2014), we use the Herfindahl-Hirschman Index $(H H I)$ for each industry in the CSRC classification and the number of competitors in the same industry (Indn) to capture product market competition. We include above proxies for product market competition as control variables and run the regression of model (3). The results are reported in Table 8. The coefficients of HHI and Indn are significant, indicating that firms in a more severe competitive product market have higher stock price synchronicity. The coefficients of $A d_{i, t}$ in columns (1) and (2) are still negative and statistically significant at the $1 \%$ level. Our findings remain the same after the additional control for product market competition.

\section{Conclusion}

Using a sample of 1,840 Chinese listed firms (9,360 firm-year data) that disclose advertising expenditures from 2009 to 2017, we find that firms with greater advertising 
Table 8 Additional control variables

\begin{tabular}{lll}
\hline Variable & $(1)$ & $(2)$ \\
\hline Ad & Syn & Syn \\
Debt & $-1.070^{\mathrm{a}}(-3.97)$ & $-1.063^{\mathrm{a}}(-3.94)$ \\
Size & $-0.260^{\mathrm{a}}(-4.27)$ & $-0.263^{\mathrm{a}}(-4.32)$ \\
Mb & $0.017(1.03)$ & $0.017(1.06)$ \\
Turnover & $-0.043^{\mathrm{b}}(-2.38)$ & $-0.044^{\mathrm{b}}(-2.40)$ \\
Big4 & $-0.109^{\mathrm{a}}(-12.28)$ & $-0.108^{\mathrm{a}}(-12.16)$ \\
Age & $-0.135^{\mathrm{a}}(-3.24)$ & $-0.136^{\mathrm{a}}(-3.24)$ \\
Roa & $0.050^{\mathrm{a}}(2.84)$ & $0.050^{\mathrm{a}}(2.83)$ \\
Institution & $-0.051(-0.26)$ & $-0.048(-0.24)$ \\
Top1 & $-0.241^{\mathrm{a}}(-4.67)$ & $-0.240^{\mathrm{a}}(-4.63)$ \\
Msh & $-0.183^{\mathrm{a}}(-2.74)$ & $-0.179^{\mathrm{a}}(-2.68)$ \\
Independent & $0.014(0.68)$ & $0.014(0.68)$ \\
HHI & $0.088(0.56)$ & $0.079(0.51)$ \\
Indn & $-0.687^{\mathrm{a}}(-2.64)$ & \\
_Cons & & $1.674^{\mathrm{c}}(1.96)$ \\
Year fixed effects & $0.314(0.84)$ & $0.242(0.65)$ \\
Industry fixed effects & Yes & Yes \\
No. of obs. & Yes & Yes \\
Adj. $R^{2}$ & 9,360 & 9.360 \\
\hline
\end{tabular}

Notes. Numbers in parentheses are $t$-statistics based on standard errors clustered by firm when we control for year and industry effects. ${ }^{\mathrm{a}}, \mathrm{b}$, and ${ }^{\mathrm{c}}$ denote statistical significance at the $1 \%, 5 \%$, and $10 \%$ levels, respectively

expenditures have lower stock price synchronicity. This finding still holds after a battery of sensitive tests (i.e., adopting the 2SLS instrumental variable model, the PSM procedure, and changing the measurement of advertising intensity and fixed effects model). Further analyses show that the impact of advertising on synchronicity is more pronounced for firms with more R\&D investment, greater dispersion among analysts' forecasts, higher stock illiquidity and firms in consumer-product industry. Moreover, we find that product market advertising enhances the informativeness of stock prices about future earnings (i.e., the FERC), ruling out the alternative explanation that the decline in synchronicity is the consequence of sentiment-driven noise trading affected by advertising. Overall, our findings provide support for the notion that product market advertising plays an informative role in the capital market, facilitating the incorporation of firm-specific information into stock prices.

Our study adds to the growing literature on product market advertising and its spillover effect on the capital market. We focus on the role of product market advertising in reducing stock price synchronicity and provide new evidence for the economic consequences of product market advertising. We also extend prior studies on stock price synchronicity by identifying a new factor that has an incremental mitigating effect on co-movement in stock prices. This paper provides further evidence to support the link between the product market and the capital market by showing that advertising campaigns conducted by firms play an important role in increasing firm-specific information incorporated into stock prices. 


\section{Appendix}

Table 9 Variable descripition

\begin{tabular}{|c|c|}
\hline Variable & Description \\
\hline$\overline{S y n_{i, t}}$ & $\begin{array}{l}\text { Syn } \\
\text {, it is stock price synchronicity for firm } i \text { during year } t, \operatorname{Syn}=\log \left(R^{2} /\left(1-R^{2}\right)\right) \text {, where } R^{2} \text { is the } \\
\text { coefficient of determination from the estimation of model }(1) \text { using daily return of the Shanghai } \\
\text { and Shenzhen Exchange stocks with a minimum of } 30 \text { daily observations. }\end{array}$ \\
\hline$A d_{i, t}$ & Advertising intensity, calculated by the advertising expenses scaled by the sales revenue in year $t$. \\
\hline Debt $_{i, t}$ & $\begin{array}{l}\text { Firm financial leverage, calculated by the book value of total liabilities divided by the book value } \\
\text { of total assets in year } t \text {. }\end{array}$ \\
\hline Size $_{i, t}$ & The natural logarithm of the book value of total assets in year $t$. \\
\hline$M b_{i, t}$ & $\begin{array}{l}\text { Market to book ratio, calculated by the sum of the market value of tradable shares and book } \\
\text { value of non-tradable shares divided by the book value of total assets in year } t \text {. }\end{array}$ \\
\hline Turnover $_{i, t}$ & $\begin{array}{l}\text { The total number of shares traded in a year divided by the total number of shares outstanding } \\
\text { at the end of year } t \text {. }\end{array}$ \\
\hline Big $_{i, t}$ & $\begin{array}{l}\text { A dummy variable that equals } 1 \text { if the firm hires an international Big4 accounting firm in year } t \\
\text { and } 0 \text { otherwise. }\end{array}$ \\
\hline $\mathrm{Age}_{i, t}$ & The number of years from IPO for firm $i$. \\
\hline$R_{0} a_{i, t}$ & Return on assets, calculated by net profit divided by the book value of total assets in year $t$. \\
\hline Institution $_{i, t}$ & The percentage of shares held by institutional owners in year $t$. \\
\hline Top $1_{i, t}$ & The percentage of shares owned by the largest shareholder in year $t$. \\
\hline$M s h_{i, t}$ & A dummy variable that equals 1 if top managers hold shares and 0 otherwise. \\
\hline Independent $t_{i, t}$ & The percentage of independent directors on a board in year $t$. \\
\hline N_Ad $d_{i, t}$ & $\begin{array}{l}\text { The mean of advertising intensity of firms in the same industry for firm } i \text { in year } t \text {, excluding the } \\
\text { firm } i \text {. }\end{array}$ \\
\hline$A d_{-} l_{i, t}$ & Advertising expenditure scaled by total assets in year $t$. \\
\hline$A d \_z_{i, t}$ & The natural logarithm of one plus advertising expenditure in year $t$. \\
\hline$R D_{i, t}$ & R\&D intensity, calculated by the R\&D expenditure divided by net sales for firm $i$ in year $t$. \\
\hline DISPEN & The standard deviation of all earnings estimates across analysts covering firm $i$ in year $t$. \\
\hline $\operatorname{ILLIQ} Q_{i, t}$ & $\begin{array}{l}\text { Stock illiquidity, calculated by the square root of the absolute value of stock return divided by } \\
\text { trade volume for firm } i \text { in year } t \text {. }\end{array}$ \\
\hline $\operatorname{CONSU}_{i, t}$ & $\begin{array}{l}\text { A dummy variable that equals } 1 \text { if the industry of firm } i \text { is classified as "consumer discretionary" } \\
\text { or "consumer staples" in WIND database and } 0 \text { otherwise. }\end{array}$ \\
\hline$R_{i, t}$ & Cumulative buy-and-hold return for firm $i$ in year $t$. \\
\hline Earnings $_{i, t}$ & The income scaled by beginning market value of equity for firm $i$ in year $t$. \\
\hline$B m_{i, t}$ & Book-to-market ratio at the beginning of year $t$. \\
\hline Growth $_{i, t}$ & The growth rate in sales revenue from the beginning of the year to the end of year $t$. \\
\hline Coverage $_{i, t}$ & The natural logarithm of the sum of the number of analysts covering firm $i$ plus 1 in year $t$. \\
\hline$H H I_{i, t}$ & The sum of squared market shares of all firms in an industry for firm $i$ in year $t$. \\
\hline $\operatorname{lndn} n_{i, t}$ & The number of competitors in the same industry for firm $i$ in year $t$. \\
\hline
\end{tabular}

\section{Acknowledgements}

Not applicable

\section{Authors' contributions}

YC analyzed and interpreted the data; QZ wrote the academic theory; FJ made the research design. The author(s) read and approved the final manuscript.

\section{Funding}

The paper is supported by National Natural Science Foundation of China (No. 71902183). 
Availability of data and materials

The data used in this article is publicly available.

\section{Competing interests}

The authors declare that they have no competing interests.

Received: 8 November 2019 Accepted: 19 March 2020

Published online: 11 May 2020

\section{References}

Abdoh, H., \& Varela, O. (2017). Product market competition, idiosyncratic and systematic volatility. Journal of Corporate Finance, 43, 500-513.

Aman, H., Kasuga, N., \& Moriyasu, H. (2017). Corporate advertisements and the investor attention effect: Evidence from television commercials. Available at SSRN 2991415.

Barber, B. M., \& Odean, T. (2008). All that glitters: The effect of attention and news on the buying behavior of individual and institutional investors. Review of Financial Studies, 21(2), 785-818.

Barth, M. E., Kasznik, R., \& Mcnichols, M. F. (2001). Analyst coverage and intangible assets. Journal of Accounting Research, 39(1), $1-34$.

Ben-Nasr, H., \& Cosset, J. (2014). State ownership, political institutions, and stock price informativeness: Evidence from privatization. Journal of Corporate Finance, 29, 179-199.

Boubaker, S., Mansali, H., \& Rjiba, H. (2014). Large controlling shareholders and stock price synchronicity. Journal of Banking and Finance, 40(3), 80-96.

Brander, J. A., \& Lewis, T. R. (1986). Oligopoly and financial structure: The limited liability effect. The American Economic Review, 76(5), 956-970.

Bustamante, M. C., \& Donangelo, A. (2017). Product market competition and industry returns. Review of Financial Studies, $30(12), 4216-4266$.

Chamberlin, E. H. (1933). The theory of monopolistic competition. Cambridge, MA: Harvard University Press.

Chan, K., \& Chan, Y. C. (2014). Price informativeness and stock return synchronicity: Evidence from the pricing of seasoned equity offerings. Journal of Financial Economics, 114(1), 36-53.

Chan, K., \& Hameed, A. (2006). Stock price synchronicity and analyst coverage in emerging markets. Journal of Financial Economics, 80(1), 115-147.

Chemmanur, T. J., \& Yan, A. (2009). Product market advertising and new equity issues. Journal of Financial Economics, 92(1), 40-65.

Choi, J. H., Choi, S., Myers, L. A., \& Ziebart, D. (2019). Financial statement comparability and the informativeness of stock prices about future earnings. Contemporary Accounting Research, 36(1), 389-417.

Corwin, S. A., \& Coughenour, J. F. (2008). Limited attention and the allocation of effort in securities trading. Journal of Finance, 63(6), 3031-3067.

Ding, R., \& Hou, W. (2015). Retail investor attention and stock liquidity. Journal of International Financial Markets, Institutions and Money, 37, 12-26.

Eckard, E. W. (1987). Advertising, competition, and market share instability. Journal of Business, 60(4), 539-552.

Fernandes, N., \& Ferreira, M. A. (2009). Insider trading laws and stock price informativeness. Review of Financial Studies, 22(5), 1845-1887.

Fich, E. M., Starks, L. T., \& Tran, A. L. (2014). Advertising, attention, and acquisition returns. Available at SSRN 2526509.

Frankel, R. M., \& Li, X. (2004). Characteristics of a firm's information environment and the information asymmetry between insiders and outsiders. Journal of Accounting and Economics, 37(2), 229-259.

Frieder, L., \& Subrahmanyam, A. (2005). Brand perceptions and the market for common stock. Journal of Financial and Quantitative Analysis, 40(1), 57-85.

Gaspar, J. M., \& Massa, M. (2006). Idiosyncratic volatility and product market competition. Journal of Business, 79(6), 3125-3152.

Gordon, B. R., \& Hartmann, W. R. (2013). Advertising effects in presidential elections. Marketing Science, 32(1), 19-35.

Grossman, G. M., \& Shapiro, C. (1984). Informative advertising with differentiated products. The Review of Economic Studies, $51(1), 63-81$.

Grossman, S. J., \& Stiglitz, J. E. (1980). On the impossibility of informationally efficient markets. The American Economic Review, 70(3), 393-408.

Grullon, G., Kanatas, G., \& Weston, J. P. (2004). Advertising, breadth of ownership, and liquidity. Review of Financial Studies, $17(2), 439-461$.

Gu, F., \& Wang, W. (2005). Intangible assets, information complexity, and analysts' earnings forecasts. Journal of Business Finance \& Accounting, 32(9), 1673-1702.

Gul, F. A., Kim, J., \& Qiu, A. A. (2010). Ownership concentration, foreign shareholding, audit quality, and stock price synchronicity: Evidence from China. Journal of Financial Economics, 95(3), 425-442.

Gurun, U. G., \& Butler, A. W. (2012). Don't believe the hype: Local media slant, local advertising, and firm value. The Journal of Finance, 67(2), 561-598.

Haggard, K. S., Martin, X., \& Pereira, R. (2008). Does voluntary disclosure improve stock price informativeness? Financial Management, 37(4), 747-768.

Hasan, I., Song, L., \& Wachtel, P. (2014). Institutional development and stock price synchronicity: Evidence from China. Journal of Comparative Economics, 42(1), 92-108.

Haw, I. M., Hu, B., Lee, J. J., \& Wu, W. (2016). The impact of industry concentration on the market's ability to anticipate future earnings. International Journal of Accounting and Information Management, 24(4), 443-475.

Ho, Y. K., Keh, H. T., \& Ong, J. M. (2005). The effects of R\&D and advertising on firm value: An examination of manufacturing and nonmanufacturing firms. IEEE Transactions on Engineering Management, 52(1), 3-14.

Holmstrom, B., \& Tirole, J. (1993). Market liquidity and performance monitoring. Journal of Political Economy, 101(4), 678-709. 
Hong, H., Torous, W., \& Valkanov, R. (2007). Do industries lead stock markets?. Journal of Financial Economics, 83(2), 367-396. Huberman, G. (2001). Familiarity breeds investment. Review of Financial Studies, 14(3), 659-680.

Huberman, G., \& Regev, T. (2001). Contagious speculation and a cure for cancer: A non-event that made stock prices soar. Journal of Finance, 56(1), 387-396.

Jiang, L., Kim, J. B., \& Pang, L. (2018). Foreign institutional investors and stock return comovement. Frontiers of Business Research in China, 12(3), 203-233.

Joseph, K., \& Wintoki, M. B. (2013). Advertising investments, information asymmetry, and insider gains. Journal of Empirical Finance, 22, 1-15.

PANG, J., Keh, H. T., \& PENG, S. (2009). Effects of advertising strategy on consumer-brand relationships: A brand love perspective. Frontiers of Business Research in China, 3(4), 599-620.

Kelly, P. J. (2014). Information efficiency and firm-specific return variation. The Quarterly Journal of Finance, 4(4), 1450018.

Kim, J. B., \& Shi, H. (2010). Voluntary IFRS adoption and stock price synchronicity: Do analyst following and institutional infrastructure matter? Available at SSRN 1586657.

Kim, J. B., Zhang, H., Li, L., \& Tian, G. (2014). Press freedom, externally-generated transparency, and stock price informativeness: International evidence. Journal of Banking \& Finance, 46, 299-310.

Krishnaswami, S., \& Subramaniam, V. (1999). Information asymmetry, valuation, and the corporate spin-off decision. Journal of Financial Economics, 53(1), 73-112.

Kyle, A. S., \& Vila, J. (1991). Noise trading and takeovers. The Rand Journal of Economics, 22(1), 54-71.

Li, H. (2016). Advertising and consumer culture in China. Hoboken: Wiley.

Li, K., \& Zhao, X. (2008). Asymmetric information and dividend policy. Financial Management, 37(4), 673-694.

Lou, D. (2014). Attracting investor attention through advertising. The Review of Financial Studies, 27(6), 1797-1829.

Luo, X., \& de Jong, P. J. (2012). Does advertising spending really work? The intermediate role of analysts in the impact of advertising on firm value. Journal of the Academy of Marketing Science, 40(4), 605-624.

Madsen, J. M., \& Niessner, M. (2019). Is investor attention for sale? The role of advertising in financial markets. Journal of Accounting Research, 57(3), 763-795.

Malkiel, B. G.. \& Fama, E. F. (1970). Efficient capital markets: A review of theory and empirical work. The Journal of Finance, 25(2), 383-417.

Markarian, G., \& Santalo, J. (2014). Product market competition, information and earnings management. Journal of Business Finance \& Accounting, 41(5-6), 572-599.

Meurer, M. J., \& Stahl, D. O. (1994). Informative advertising and product match. International Journal of Industrial Organization, 12(1), 1-19.

Morck, R., Yeung, B., \& Yu, W. (2000). The information content of stock markets: Why do emerging markets have synchronous stock price movements? Journal of Financial Economics, 58(1), 215-260.

Morellec, E., \& Zhdanov, A. (2019). Product market competition and option prices. The Review of Financial Studies, 32(11), 4343-4386.

Nelson, P. (1970). Information and consumer behavior. Journal of Political Economy, 78(2), 311-329.

Nelson, P. (1974). Advertising as information. Journal of Political Economy, 82(4), 729-754.

Oh, H., Bae, J., \& Kim, S. (2017). Can sinful firms benefit from advertising their CSR efforts? Adverse effect of advertising sinful firms' CSR engagements on firm performance. Journal of Business Ethics, 143(4), 643-663.

Peress, J. (2010). Product market competition, insider trading and stock market efficiency. Journal of Finance, 65(1), 1-43.

Piotroski, J. D., \& Roulstone, D. T. (2004). The influence of analysts, institutional investors, and insiders on the incorporation of market, industry, and firm-specific information into stock prices. The Accounting Review, 79(4), 1119-1151.

Serfling, M. A. (2014). CEO age and the riskiness of corporate policies. Journal of Corporate Finance, 25, 251-273.

Simpson, A. V. (2008). Voluntary disclosure of advertising expenditures. Journal of Accounting, Auditing \& Finance, 23(3), 403436.

Stoll, H. R. (2000). Presidential address: Friction. Journal of Finance, 55(4), 1479-1514.

Telser, L. G. (1964). Advertising and competition. Journal of Political Economy, 72(6), 537-562.

Thomas, S. (2002). Firm diversification and asymmetric information: Evidence from analysts' forecasts and earnings announcements. Journal of Financial Economics, 64(3), 373-396.

Valta, P. (2012). Competition and the cost of debt. Journal of Financial Economics, 105(3), 661-682.

Yang, Y., \& Zhang, Y. (2006). R-squared: Noise or firm-specific information. Working paper, The Chinese University of Hong Kong.

\section{Publisher's Note}

Springer Nature remains neutral with regard to jurisdictional claims in published maps and institutional affiliations. 